J. Phys. Chem. C

Manuscript ID jp-2015-12768t

Supporting Information

\title{
Enhancement of Photoinduced Visible Light Degradation of Salicylic Acid by Covalently-Attached Synthetic Flavins on BiOCI Semiconductor Particle Surfaces
}

\author{
Malka Rochkind, ${ }^{1}$ Manjula Pandiri, ${ }^{1}$ Mohammad S. Hossain, ${ }^{2}$ Frank W. Foss Jr., ${ }^{2}$ Krishnan \\ Rajeshwar ${ }^{2}$ and Yaron $\mathrm{Paz}^{1 *}$ \\ ${ }^{1}$ Department of Chemical Engineering, Technion, Haifa 32000, Israel \\ ${ }^{2}$ Department of Chemistry, University of Texas at Arlington, Arlington, TX, USA \\ *Corresponding author, Email: paz@tx.technion.ac.il
}

Synthetic Details ...

Spectra For Synthetic Compounds ...

XRD and SEM Data on BiOCl Particles ...

Salicylic Acid Degradation kinetics data ...

Diffuse reflectance UV-Vis data of $\mathrm{BiOCl}$ particles and SA . .

S-20 


\section{Synthetic Details}

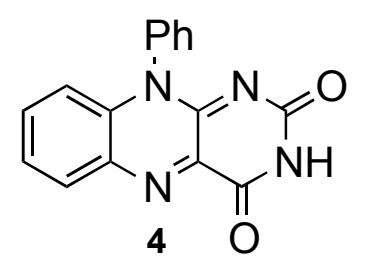

10-phenylisoalloxazine, 4: Alloxan monohydrate (10.0 g, $62.5 \mathrm{mmol}), \mathrm{N}$ phenyl-o-phenylenediamine $(11.5 \mathrm{~g}, 62.5 \mathrm{mmol})$ and boric acid $(3.9 \mathrm{~g}$, $62.5 \mathrm{mmol}$ ) were added to $250 \mathrm{~mL}$ of glacial acetic acid and the solution was stirred overnight $(\sim 15 \mathrm{~h})$. The product precipitated as a dark yellow solid. The resultant solid was filtered through celite and washed with acetic acid $(20 \mathrm{~mL})$ followed by deionized water. Finally, the solid was washed with diethyl ether and dried in a desiccator to yield compound 4.8 as a light yellow solid $(15.8 \mathrm{~g}, 87 \%), \mathrm{mp}:>400{ }^{\circ} \mathrm{C},{ }^{1} \mathrm{H}$ NMR $\left(500 \mathrm{MHz}, \mathrm{DMSO}-d_{6}\right) \delta 11.43(\mathrm{~s}$, 1H), $8.40-8.04$ (m, 1H), $7.95-7.57(\mathrm{~m}, 5 \mathrm{H}), 7.45(\mathrm{~s}, 2 \mathrm{H}), 6.96-6.57(\mathrm{~m}, 1 \mathrm{H}) .{ }^{13} \mathrm{C}$ NMR $(126$ MHz, DMSO- $\left.d_{6}\right) \delta 159.6,155.6,151.8,139.5,136.1,134.8$ (2 peaks), 134.1, 131.4, 130.3, $129.8,127.8,126.0,116.8$.<smiles>O=C(O)CCCn1c(=O)nc2n(-c3ccccc3)c3ccccc3nc-2c1=O</smiles>

10-phenylisoalloxazine $4.8(1 \mathrm{mmol})$ and $\mathrm{K}_{2} \mathrm{CO}_{3}(4 \mathrm{mmol})$ and

6 hours and a dark yellow solid formed. The solid was filtered and washed with $20 \mathrm{ml}$ of DMF. The resultant solid was used for the next step without any further purification. The solid was suspended in $50 \mathrm{ml}$ of DMF and alkylating agent (4.10a-c, $3 \mathrm{mmol}$ ) was added and stirred at room temperature to $50{ }^{\circ} \mathrm{C}$. The reaction mixture was filtered and the filtrate was dried under a stream of air. The resultant solid was dissolved in DCM-water (1:1) and the compound was extracted with $3 \times 50 \mathrm{ml}$ of DCM. The organic layer was dried over $\mathrm{MgSO}_{4}$ and solvent was 
removed and flash chromatography was used with $1-2 \mathrm{MeOH}$ in DCM to purify the product as yellow solid; $\mathrm{mp}=250{ }^{\circ} \mathrm{C}(\mathrm{dec}),{ }^{1} \mathrm{H}$ NMR $(500 \mathrm{MHz}, \mathrm{CDCl} 3) \delta 8.33(\mathrm{dd}, J=8.2,1.3 \mathrm{~Hz}, 1 \mathrm{H})$, $7.71-7.54(\mathrm{~m}, 5 \mathrm{H}), 7.33-7.27(\mathrm{~m}, 2 \mathrm{H}), 6.89(\mathrm{~d}, J=8.5 \mathrm{~Hz}, 1 \mathrm{H}), 4.18-4.05(\mathrm{~m}, 4 \mathrm{H}), 2.40(\mathrm{t}, J$ $=7.7 \mathrm{~Hz}, 2 \mathrm{H}), 2.06(\mathrm{p}, J=7.4 \mathrm{~Hz}, 2 \mathrm{H}), 1.24(\mathrm{t}, J=7.1 \mathrm{~Hz}, 3 \mathrm{H}) .{ }^{13} \mathrm{C} \mathrm{NMR}(126 \mathrm{MHz}, \mathrm{CDCl} 3) \delta$ $173.05,159.52,155.24,150.15,137.92,135.78,135.47,135.14,134.30,132.79,130.96,130.61$, $127.66,126.69,117.18,60.55,41.43,32.03,23.33,14.36$. The ester intermediate ( $2 \mathrm{mmol})$ was mixed with $50 \mathrm{ml}$ of $5 \mathrm{M} \mathrm{HCl}$ and the mixture was heated at $90{ }^{\circ} \mathrm{C}$ for $6 \mathrm{hr}$. The reaction turned transparent and the solvent was removed by using rotary evaporator. The dried reaction mixture was diluted with distilled water and a yellow solid formed. The mixture was stirred for $3 \mathrm{hr}$ and filtered to get the product. The product was washed with diethyl ether to isolate compound 1a (72\%) as yellow solid. ${ }^{1} \mathrm{H}$ NMR (500 MHz, DMSO- $\left.d_{6}\right) \delta 8.23(\mathrm{~d}, J=8.1 \mathrm{~Hz}, 1 \mathrm{H}), 7.80-7.61$ (m, 5H), $7.44(\mathrm{~d}, J=7.3 \mathrm{~Hz}, 2 \mathrm{H}), 6.79(\mathrm{~d}, J=8.5 \mathrm{~Hz}, 1 \mathrm{H}), 3.91(\mathrm{t}, J=6.8 \mathrm{~Hz}, 2 \mathrm{H}), 2.26(\mathrm{t}, J=$ $7.5 \mathrm{~Hz}, 2 \mathrm{H}), 1.81$ (p, $J=7.3 \mathrm{~Hz}, 2 \mathrm{H}) .{ }^{13} \mathrm{C}$ NMR (126 MHz, DMSO- $\left.D_{6}\right) \delta 174.0,159.2,154.8$, $150.4,138.7,135.8,134.9,133.9,131.4,130.4,129.9,127.8,126.1,116.8,40.2,39.5,31.1,22.9$.<smiles></smiles>

10-phenylisoalloxazine $6.14(500 \mathrm{mg}, 1.72 \mathrm{mmol})$ was heated with $\mathrm{K}_{2} \mathrm{CO}_{3}(600 \mathrm{mg}, 4.3 \mathrm{mmol})$ at $105{ }^{\circ} \mathrm{C}$ for $4 \mathrm{~h}$ in $50 \mathrm{ml}$ of DMF, the resultant dark yellow solid $\left(\mathrm{K}^{+}\right.$salt of 7) was filtered and rinsed with ether and dried. The solid was then suspended in $50 \mathrm{ml}$ of DMF and $\mathbf{5 b}(534 \mathrm{mg}, 2.1 \mathrm{mmol})$, was added and stirred overnight. The reaction mixture was filtered and the filtrate was dried under a stream of dry air. The resultant solid was dissolved in DCM-water (1:1) and the compound was extracted with $3 \times 50 \mathrm{ml}$ of DCM. The organic layer was dried over $\mathrm{MgSO}_{4}$ and solvent was removed and flash chromatography was 
used with $2 \% \mathrm{MeOH}$ in DCM to purify the product as yellow solid. The diethylphosphonate was purified as a dark yellow solid (580 mg, $72 \%$ over two steps). IR $\left(\mathrm{cm}^{-1}\right)$ : 1644, 1549, 1256, 1012. $\mathrm{mp}=240{ }^{\circ} \mathrm{C}(\mathrm{dec}),{ }^{1} \mathrm{H}$ NMR $\left(500 \mathrm{MHz}, \mathrm{CDCl}_{3}\right) \delta 8.32(\mathrm{~d}, J=8.0 \mathrm{~Hz}, 1 \mathrm{H}), 7.77-7.52(\mathrm{~m}$, $5 \mathrm{H}), 7.30(\mathrm{~d}, J=7.3 \mathrm{~Hz}, 2 \mathrm{H}), 6.89(\mathrm{~d}, J=8.5 \mathrm{~Hz}, 1 \mathrm{H}), 4.27-3.99(\mathrm{~m}, 6 \mathrm{H}), 2.16-1.93(\mathrm{~m}, 2 \mathrm{H})$, $1.89-1.75(\mathrm{~m}, 2 \mathrm{H}), 1.29(\mathrm{t}, J=6.9 \mathrm{~Hz}, 6 \mathrm{H}) .{ }^{13} \mathrm{C} \mathrm{NMR}\left(125 \mathrm{MHz}, \mathrm{CDCl}_{3}\right) \delta$ 159.44, 155.11, $150.14,137.87,135.77,135.49,135.11,134.28,132.75,130.92,130.58,127.63,126.70,117.18$, 61.74, 61.69, 42.39, 42.23, 24.13, 23.00, 21.21, 16.61, 16.56. ${ }^{31} \mathrm{P}$ NMR (122 MHz, CDCL3) $\delta$ 31.79. HRMS: $[\mathrm{M}+\mathrm{Na}$ ] 491.1450, predicted $\mathrm{m} / \mathrm{z}=491.1455$. The diester intermediate of $\mathbf{1 b}$ (300 mg, $0.64 \mathrm{mmol}$ ) was dissolved in $25 \mathrm{ml}$ of dry dichloromethane and bromotrimetylsilane $(660 \mu 1,3.2 \mathrm{mmol})$ was added dropwise and stirred at room temperature under argon for overnight. The solvent was removed by using rotary evaporator and $20 \mathrm{ml}$ of methanol was added and stirred for $14 \mathrm{hr}$. The solvent was removed by rotary evaporator and deionized water was added and stirred for $2 \mathrm{hr}$. A yellow solid started to form and the product $6.3(211 \mathrm{mg}, 80 \%)$ was isolated by filtration and washed with diethyl ether and dichloromethane. IR $\left(\mathrm{cm}^{-1}\right): 1551$, $1265,1226,1022, \mathrm{mp}=189{ }^{\circ} \mathrm{C}(\mathrm{dec}){ }^{1} \mathrm{H}$ NMR: ${ }^{1} \mathrm{H}$ NMR $\left(500 \mathrm{MHz}\right.$, DMSO- $\left.d_{6}\right) \delta 8.44-8.01$ (m, 1H), $7.99-7.57(\mathrm{~m}, 5 \mathrm{H}), 7.45(\mathrm{~s}, 2 \mathrm{H}), 6.79(\mathrm{~s}, 1 \mathrm{H}), 3.91(\mathrm{~s}, 2 \mathrm{H}), 1.78(\mathrm{~s}, 2 \mathrm{H}), 1.55(\mathrm{~s}, 2 \mathrm{H})$ ${ }^{13} \mathrm{C}$ NMR $\left(126 \mathrm{MHz}\right.$, DMSO- $\left.d_{6}\right) \delta 159.2,154.8,150.4,138.7,135.9,134.9,134.9,134.0,131.4$, $130.4,129.9,127.8,126.1,116.8,41.7,25.9,24.8,21.5 .{ }^{31} \mathrm{P}$ NMR (122 MHz, DMSO-D 6 ) $\delta$ 29.44. HRMS: $[\mathrm{M}+\mathrm{H}]$ 413.0997, predicted $\mathrm{m} / \mathrm{z}=413.1009$

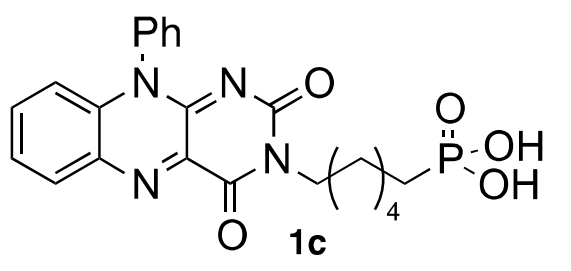

10-phenylisoalloxazine $6.14(2.0 \mathrm{~g}, 6.9 \mathrm{mmol})$ was heated with $\mathrm{K}_{2} \mathrm{CO}_{3}(2.6 \mathrm{~g}, 18.8 \mathrm{mmol})$ at $105{ }^{\circ} \mathrm{C}$ for $4 \mathrm{hr}$ in $\mathrm{DMF}$, the 
resultant dark yellow solid (K salt of 6.14) was filtered and rinsed with ether and dried. The solid was then suspended in $150 \mathrm{ml}$ of DMF and $6.21(2.2 \mathrm{~g}, 7.2 \mathrm{mmol})$, was added and stirred overnight. The reaction mixture was filtered and the filtrate was dried by blowing air. The resultant solid was dissolved in DCM-water (1:1) and the compound was extracted with $3 \times 50 \mathrm{ml}$ of DCM. The organic layer was dried over $\mathrm{MgSO}_{4}$ and solvent was removed and flash chromatography was used with $2 \% \mathrm{MeOH}$ in DCM to purify the product as yellow solid. The product 6.26 was purified as dark yellow solid ( $2.5 \mathrm{~g}, 70 \%$ in two steps $) . \mathrm{mp}=200-202{ }^{\circ} \mathrm{C}$, IR $\left(\mathrm{cm}^{-1}\right): 1645,1551,1258,1030,{ }^{1} \mathrm{H}$ NMR $\left(500 \mathrm{MHz}, \mathrm{CDCl}_{3}\right) \delta 8.35-8.28(\mathrm{~m}, 1 \mathrm{H}), 7.71-7.58$ (m, 5H), $7.29(\mathrm{~d}, J=7.3 \mathrm{~Hz}, 2 \mathrm{H}), 6.87(\mathrm{~d}, J=8.3 \mathrm{~Hz}, 1 \mathrm{H}), 4.14-3.97(\mathrm{~m}, 6 \mathrm{H}), 1.69$ (ddd, $J=$ 14.8, 10.9, $7.3 \mathrm{~Hz}, 4 \mathrm{H}), 1.63-1.52(\mathrm{~m}, 2 \mathrm{H}), 1.46-1.33(\mathrm{~m}, 4 \mathrm{H}), 1.29(\mathrm{t}, J=7.1 \mathrm{~Hz}, 6 \mathrm{H}) .{ }^{13} \mathrm{C}$ NMR $\left(126 \mathrm{MHz}, \mathrm{CDCl}_{3}\right) \delta 159.41,155.25,150.08,137.95,135.73,135.38,135.13,134.28$, $132.73,130.92,130.56,127.67,126.62,117.14,61.54,61.48,42.07,30.53,30.40,27.67,26.56$, 26.30, 25.18, 22.53, 22.49, 16.63, 16.58. ${ }^{31} \mathrm{P}$ NMR (122 MHz, CDCL3) $\delta 33.13$. HRMS : [M+H] 511.2131, predicted $\mathrm{m} / \mathrm{z}=511.2110$ The diethyl phosphonate $(900 \mathrm{mg}, 1.8 \mathrm{mmol})$ was dissolved in $100 \mathrm{ml}$ of dry dichloromethane and bromotrimetylsilane $(1.6 \mathrm{ml}, 8.8 \mathrm{mmol})$ was added drop wise and stirred at room temperature under Argon for overnight. The solvent was removed by using rotary evaporator and $50 \mathrm{ml}$ of methanol was added and stirred for $14 \mathrm{hr}$. The solvent was removed using rotary evaporator and Deionized water was added and stirred for $2 \mathrm{hr}$. A yellow solid started to form and the product $6.4(605.3 \mathrm{mg}, 78 \%)$ was isolated by filtration and washed with water and diethyl ether. Melting point $=185^{\circ} \mathrm{C}(\mathrm{dec}), \operatorname{IR}\left(\mathrm{cm}^{-1}\right): 3472,1643,1549$, 1135, 997. ${ }^{1} \mathrm{H}$ NMR $\left(500 \mathrm{MHz}, \mathrm{DMSO}-d_{6}\right) \delta 8.23(\mathrm{~d}, J=8.0 \mathrm{~Hz}, 1 \mathrm{H}), 7.79-7.60(\mathrm{~m}, 5 \mathrm{H}), 7.45$ $(\mathrm{d}, J=7.4 \mathrm{~Hz}, 2 \mathrm{H}), 6.78(\mathrm{~d}, J=8.5 \mathrm{~Hz}, 1 \mathrm{H}), 3.86(\mathrm{t}, J=7.2 \mathrm{~Hz}, 2 \mathrm{H}), 1.64-1.19(\mathrm{~m}, 10 \mathrm{H}) \cdot{ }^{13} \mathrm{C}$ NMR (126 MHz, DMSO- $\left.D_{6}\right) \delta 159.09,154.73,150.37,138.63,135.87,135.00,134.88,133.99$, 
$131.43,130.35,129.91,127.86,126.06,116.77,40.90,39.52,29.93,29.80,28.15,27.25,27.08$ 26.12, 22.80, 22.77. ${ }^{31} \mathrm{P}$ NMR (122 MHz, DMSO- $\left.D_{6}\right) \delta$ 26.94. HRMS: $[\mathrm{M}+\mathrm{H}]$ 455.1486; predicted $\mathrm{m} / \mathrm{z}=455.1479$<smiles></smiles>

10-phenylisoalloxazine $6.14(2.0 \mathrm{~g}, 6.9 \mathrm{mmol})$ was heated with $\mathrm{K}_{2} \mathrm{CO}_{3}(2.6 \mathrm{~g}, 18.8 \mathrm{mmol})$ at $105^{\circ} \mathrm{C}$ for $4 \mathrm{hr}$ in $\mathrm{DMF}$, the resultant dark yellow solid (K salt of 6.14) was filtered and rinse with ether and dried. The solid was then suspended in $150 \mathrm{ml}$ of DMF and 6.22 (2.2 g, 6.9 mmol), was added and stirred overnight. The reaction mixture was filtered and the filtrate was dried by blowing air. The resultant solid was dissolved in DCM-water (1:1) and the compound was extracted with $3 \times 50 \mathrm{ml}$ of DCM. The organic layer was dried over $\mathrm{MgSO}_{4}$ and solvent was removed and flash chromatography was used with 1-2 $\mathrm{MeOH}$ in DCM to purify the product as yellow solid. The product 6.27 was purified as dark yellow solid ( $2.6 \mathrm{~g}, 71 \%$ in two steps). mp $=158-160{ }^{\circ} \mathrm{C}, \mathrm{IR}\left(\mathrm{cm}^{-1}\right): 3565,3461,1642,1548,1243,1019 .{ }^{1} \mathrm{H}$ NMR $\left(500 \mathrm{MHz}, \mathrm{CDCl}_{3}\right) \delta$ $8.34-8.29(\mathrm{~m}, 1 \mathrm{H}), 7.70-7.53(\mathrm{~m}, 5 \mathrm{H}), 7.30(\mathrm{~d}, J=7.3 \mathrm{~Hz}, 2 \mathrm{H}), 6.88(\mathrm{~d}, J=8.4 \mathrm{~Hz}, 1 \mathrm{H}), 4.12$ - $3.97(\mathrm{~m}, 6 \mathrm{H}), 1.74-1.62(\mathrm{~m}, 4 \mathrm{H}), 1.61-1.49(\mathrm{~m}, 2 \mathrm{H}), 1.32(\mathrm{~m}, 14 \mathrm{H}) .{ }^{13} \mathrm{C} \mathrm{NMR}(126 \mathrm{MHz}$ $\left.\mathrm{CDCl}_{3}\right) \delta 159.36,155.25,150.05,137.95,135.70,135.34,135.12,134.25,132.69,130.90$ $130.53,127.65,126.58,117.12,61.50,61.45,42.18,30.70,30.56,29.18,29.03,27.77,26.92$, 26.29, 25.18, 22.51, 22.47, 16.61, 16.56. ${ }^{31} \mathrm{P}$ NMR (122 MHz, DMSO- $\left.D_{6}\right) \delta 33.28$. HRMS : $[\mathrm{M}+\mathrm{Na}] 561.2256$, Predicted $\mathrm{m} / \mathrm{z}=561.2237$ The diethyl phosphonate $(467 \mathrm{mg}, 0.87 \mathrm{mmol})$ was dissolved in $50 \mathrm{ml}$ of dry dichloromethane and bromotrimetylsilane (572 $\mu 1,4.3 \mathrm{mmol})$ was added dropwise and stirred at room temperature under argon for overnight. The solvent was removed by using rotary evaporator and $30 \mathrm{ml}$ of methanol was added and stirred for $14 \mathrm{hr}$. The 
solvent was removed using rotary evaporator and deionized water was added and stirred for $2 \mathrm{hr}$. A yellow solid started to form and the product $6.5(293.8 \mathrm{mg}, 70 \%)$ was isolated by filtration and washed with water and diethyl ether. $\mathrm{mp}=215-218(\mathrm{dec}), \mathrm{IR}\left(\mathrm{cm}^{-1}\right): 1645,1552,1178,1001$. ${ }^{1} \mathrm{H}$ NMR $\left(500 \mathrm{MHz}\right.$, DMSO- $\left.d_{6}\right) \delta 8.23(\mathrm{~d}, J=7.7 \mathrm{~Hz}, 1 \mathrm{H}), 7.83-7.56(\mathrm{~m}, 5 \mathrm{H}), 7.45(\mathrm{~d}, J=6.9$ $\mathrm{Hz}, 2 \mathrm{H}), 6.78(\mathrm{~d}, J=8.2 \mathrm{~Hz}, 1 \mathrm{H}), 3.85(\mathrm{~s}, 2 \mathrm{H}), 1.62-1.11(\mathrm{~m}, 14 \mathrm{H}) .{ }^{13} \mathrm{C} \mathrm{NMR}(126 \mathrm{MHz}$, DMSO- $\left.D_{6}\right) \delta 159.06,154.71,150.35,138.61,135.86,135.00,134.89,133.99,131.42,130.36$, $129.92,127.87,126.07,116.78,40.89,39.52,30.11,29.98,28.63,28.11,27.33,27.03,26.40$, 22.75, 22.73. ${ }^{31} \mathrm{P}$ NMR (122 MHz, DMSO- $\left.D_{6}\right) \delta 27.43$. HRMS: $[\mathrm{M}+\mathrm{H}]$ 483.1808; predicted m/z $=483.1792$

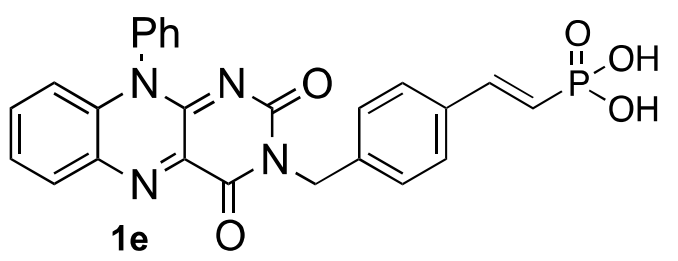

10-phenylisoalloxazine $6.14(2.0 \mathrm{~g}, 6.9 \mathrm{mmol})$ was heated with $\mathrm{K}_{2} \mathrm{CO}_{3}(2.6 \mathrm{~g}, 18.8 \mathrm{mmol})$ at $105{ }^{\circ} \mathrm{C}$ for 4 $\mathrm{hr}$ in DMF, the resultant dark yellow solid $\left(\mathrm{K}^{+}\right.$salt of 6.14) was filtered and rinse with diethyl ether and dried. The solid was then suspended in $150 \mathrm{ml}$ of DMF and 6.37 (2.3 g, $6.9 \mathrm{mmol})$, was added and stirred overnight. The reaction mixture was filtered and the filtrate was dried by blowing air. The resultant solid was dissolved in DCMwater (1:1) and the compound was extracted with $3 \times 50 \mathrm{ml}$ of DCM. The organic layer was dried over $\mathrm{MgSO}_{4}$ and solvent was removed and flash chromatography was used with $5 \% \mathrm{MeOH}$ in DCM to purify the product as yellow solid. The diethyl phosphonate product was purified as dark yellow solid with some impurity. The impurity was removed washing the solid with hexane, ether and ethyl acetate. The final product was yellow solid $(2.01 \mathrm{~g}, 54 \%) . \mathrm{mp}=296-298{ }^{\circ} \mathrm{C}$ (dec), IR $\left(\mathrm{cm}^{-1}\right): 1649,1548,1245,1053,1024 .{ }^{1} \mathrm{H}$ NMR $\left(301 \mathrm{MHz}, \mathrm{CDCl}_{3}\right) \delta 8.32(\mathrm{~d}, J=8.0$ $\mathrm{Hz}, 1 \mathrm{H}), 7.70-7.49(\mathrm{~m}, 7 \mathrm{H}), 7.48-7.34(\mathrm{~m}, 3 \mathrm{H}), 7.34-7.26(\mathrm{~m}, 2 \mathrm{H}), 6.89(\mathrm{~d}, J=8.5 \mathrm{~Hz}, 1 \mathrm{H})$, 
$6.20(\mathrm{dd}, J=17.6 \mathrm{~Hz}, 1 \mathrm{H}), 5.26(\mathrm{~s}, 2 \mathrm{H}), 4.19-4.03(\mathrm{~m}, 4 \mathrm{H}), 1.33(\mathrm{t}, J=7.0 \mathrm{~Hz}, 6 \mathrm{H}) .{ }^{13} \mathrm{C} \mathrm{NMR}$ $\left(76 \mathrm{MHz}, \mathrm{CDCl}_{3}\right) \delta 159.39,155.08,150.08,148.61,148.52,139.07,137.92,135.80,135.61$, $135.05,134.25,132.77,130.92,130.61,130.24,127.85,127.59,126.79,117.21,115.17,112.64$ 61.99, 61.92, 44.91, 16.57, 16.49. ${ }^{31} \mathrm{P}$ NMR (122 MHz, CDCL3) $\delta$ 20.24. HRMS : [M+Na] 565.1622, Predicted $\mathrm{m} / \mathrm{z}=565.1611$ the diethyl phosphonate $(1.0 \mathrm{~g}, 1.84 \mathrm{mmol})$ was dissolved in $100 \mathrm{ml}$ of dry dichloromethane and bromotrimetylsilane $(1.22 \mathrm{ml}, 9.2 \mathrm{mmol})$ was added dropwise and stirred at room temperature under argon for overnight. The solvent was removed by using rotary evaporator and $30 \mathrm{ml}$ of methanol was added and stirred for overnight. The solvent was removed using rotary evaporator and deionized water was added and stirred for 2-3 hr. A yellow solid started to form and the product 6.9 (870 mg, 97\%) was isolated by filtration and washed with water and diethyl ether. $\mathrm{mp}=254-256{ }^{\circ} \mathrm{C} . \mathrm{IR}\left(\mathrm{cm}^{-1}\right): 1641,1545,1177,985$. ${ }^{1} \mathrm{H}$ NMR (500 MHz, DMSO- $\left.d_{6}\right) \delta 8.40-8.11(\mathrm{~m}, 1 \mathrm{H}), 7.73(\mathrm{t}, J=26.2 \mathrm{~Hz}, 5 \mathrm{H}), 7.60-7.27(\mathrm{~m}$, 6H), $7.15(\mathrm{t}, J=18.8 \mathrm{~Hz}, 1 \mathrm{H}), 6.80(\mathrm{~d}, J=7.1 \mathrm{~Hz}, 1 \mathrm{H}), 6.46(\mathrm{t}, J=15.6 \mathrm{~Hz}, 1 \mathrm{H}), 5.09$ (s, 2H). ${ }^{13} \mathrm{C}$ NMR (126 MHz, DMSO- $\left.D_{6}\right) \delta 159.29,154.67,150.56,142.55,142.50,138.75,138.56$, $135.85,135.08,135.06,134.40,134.22,133.98,131.45,130.38,129.96,127.99,127.82,127.30$ 126.23, 116.86, 43.89, 40.02, 39.85, 39.69, 39.52, 39.35, 39.19, 39.02. ${ }^{31} \mathrm{P}$ NMR (122 MHz, DMSO- $\left.D_{6}\right) \delta$ 13.98. HRMS: [M+H] 487.1188; predicted $\mathrm{m} / \mathrm{z}=487.1166$

$\mathrm{Br} \mathrm{n}_{\mathrm{n}} \mathrm{PO}_{3} \mathrm{Et}_{2}$ Synthesis of 5b: 1,3-dibromopropane (12.2 g, $60.2 \mathrm{mmol}$ ) was heated to $5 b: n=1$ $5 \mathrm{c}: \mathrm{n}=4$

5d: $\mathbf{n}=\mathbf{6}$ the reaction was heated at $140{ }^{\circ} \mathrm{C}$ for $12 \mathrm{~h}$. The reaction was concentrated using a rotary evaporator and the compound was purified using flash chromatography with two column volumes of dichloromethane followed by a gradient elution from $10 \%$ diethyl ether in 
ethyl acetate to $100 \%$ ethyl acetate. Compound $\mathbf{5 b}(1.9 \mathrm{~g}, 63 \%)$ was isolated as a colorless oil. ${ }^{1} \mathrm{H}$ NMR $\left(500 \mathrm{MHz}, \mathrm{CDCl}_{3}\right) \delta$ 4.20-4.01 (m, 4H), 3.47 (t, $\left.J=6.4 \mathrm{~Hz}, 1 \mathrm{H}\right), 2.20-2.09(\mathrm{~m}, 1 \mathrm{H})$, 1.98-1.83 (m, 2H), $1.32(\mathrm{t}, J=7.1 \mathrm{~Hz}, 6 \mathrm{H}) .{ }^{13} \mathrm{C} \mathrm{NMR}\left(126 \mathrm{MHz}, \mathrm{CDCl}_{3}\right) \delta$ 61.85, 61.80, 33.81, $33.67,26.11,26.08,25.11,23.98,16.61,16.56$.

Synthesis of 5c: 1,6-dibromohexane $(5 \mathrm{ml}, 32.5 \mathrm{mmol})$ was heated at $140{ }^{\circ} \mathrm{C}$ and triethylphosphite $(5.6 \mathrm{mmol}, 32.5 \mathrm{mmol})$ was added drop wise using additional funnel. The reaction was heating at $140{ }^{\circ} \mathrm{C}$ for overnight and the reaction was concentrated using rotary evaporator. The product $5 \mathrm{c}(5.2 \mathrm{~g}, 53 \%)$ was separated as a colorless oil using column chromatography with two column volume of dichloromethane and a gradient elution with $10 \%$ hexane in ethyl acetate to $50 \%$ hexane in ethyl acetate. ${ }^{1} \mathrm{H} \mathrm{NMR}\left(500 \mathrm{MHz}, \mathrm{CHCl}_{3}\right) \delta 4.07-3.98$ (m, 4H), $3.33(\mathrm{t}, J=6.8 \mathrm{~Hz}, 2 \mathrm{H}), 1.79(\mathrm{p}, J=6.8 \mathrm{~Hz}, 2 \mathrm{H}), 1.70-1.61(\mathrm{~m}, 2 \mathrm{H}), 1.56(\mathrm{dtd}, J=$ $15.9,10.6,9.7,5.1 \mathrm{~Hz}, 2 \mathrm{H}), 1.36(\mathrm{tdt}, J=16.5,10.3,5.6 \mathrm{~Hz}, 4 \mathrm{H}), 1.25(\mathrm{t}, J=7.1 \mathrm{~Hz}, 6 \mathrm{H}) .{ }^{13} \mathrm{C}$ NMR $\left(126 \mathrm{MHz}, \mathrm{CDCl}_{3}\right) \delta 61.45,61.40,33.73,32.44,29.70,29.57,27.62,26.11,24.99,22.29$, $22.25,16.51,16.46$.

Synthesis of 5d: 1,8-dibromooctane $(5.0 \mathrm{~g}, 18.4 \mathrm{mmol})$ was heated at $140{ }^{\circ} \mathrm{C}$ and triethylphosphite (1.53 g, $9.2 \mathrm{mmol})$ was added drop wise using additional funnel. The reaction was heating at $140{ }^{\circ} \mathrm{C}$ for overnight and the reaction was concentrated using rotary evaporator. The product 5d ( $2.12 \mathrm{~g}, 70 \%$ ) was separated as a colorless oil using column chromatography with two column volume of dichloromethane and a gradient elution with $10 \%$ diethyl ether in ethyl acetate to ethyl acetate. ${ }^{1} \mathrm{H}$ NMR $\left(500 \mathrm{MHz}, \mathrm{CDCl}_{3}\right) \delta 4.16-3.97(\mathrm{~m}, 4 \mathrm{H}), 3.43-3.31(\mathrm{~m}$, $2 \mathrm{H}), 1.88-1.75(\mathrm{~m}, 2 \mathrm{H}), 1.76-1.63(\mathrm{~m}, 2 \mathrm{H}), 1.62-1.48(\mathrm{~m}, 2 \mathrm{H}), 1.45-1.19(\mathrm{~m}, 14 \mathrm{H}) .{ }^{13} \mathrm{C}$ NMR $\left(126 \mathrm{MHz}, \mathrm{CDCl}_{3}\right) \delta 61.50,61.45,34.04,32.82,30.61,30.47,28.98,28.57,28.15,26.30$, $25.18,22.46,22.42,16.59,16.55$. 


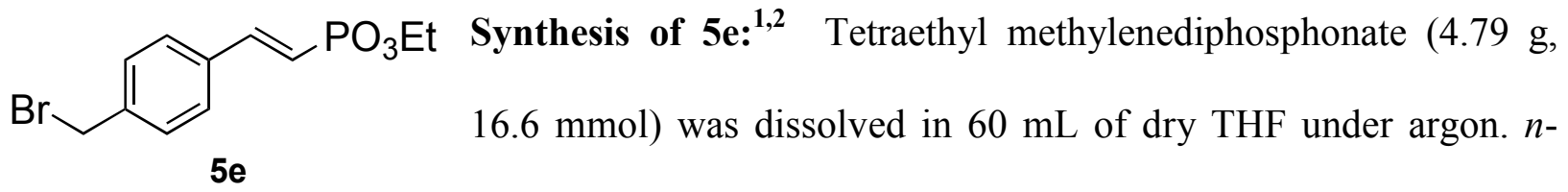
$\operatorname{BuLi}(2.5 \mathrm{M}$ in hexane, $7.3 \mathrm{ml}, 18.3 \mathrm{mmol})$ was added slowly at $78^{\circ} \mathrm{C}$ and the reaction was stirred for $20 \mathrm{~min}$. The reaction was warmed to room temperature and 4-methylbenzaldehyde ( $2.0 \mathrm{~g}, 16.6 \mathrm{mmol})$ was added and stirred overnight at room temperature. Diethyl ether $(100 \mathrm{~mL})$ and $100 \mathrm{ml}$ of $\mathrm{NaHCO}_{3}\left(1.0 \mathrm{~g}\right.$ in $\left.100 \mathrm{ml} \mathrm{H}_{2} \mathrm{O}\right)$ was added and extracted into $(100 \mathrm{ml} \times 2) \mathrm{Et}_{2} \mathrm{O}$. The product $6.36(3.8 \mathrm{~g}, 90 \%)$ was purified using flash chromatography using $2 \%$ methanol in ethyl acetate as eluent. ${ }^{1} \mathrm{H}$ NMR $\left(500 \mathrm{MHz}, \mathrm{CDCl}_{3}\right) \delta 7.47(\mathrm{dd}, J=22.6$, $17.5 \mathrm{~Hz}, 1 \mathrm{H}), 7.39$ (d, $J=8.0 \mathrm{~Hz}, 2 \mathrm{H}), 7.18(\mathrm{~d}, J=7.9 \mathrm{~Hz}, 2 \mathrm{H}), 6.19$ (dd, $J=17.7 \mathrm{~Hz}, 1 \mathrm{H}), 4.25-$ $4.01(\mathrm{~m}, 4 \mathrm{H}), 2.36(\mathrm{~s}, 3 \mathrm{H}), 1.34(\mathrm{t}, J=7.1 \mathrm{~Hz}, 6 \mathrm{H}) .{ }^{13} \mathrm{C} \mathrm{NMR}\left(126 \mathrm{MHz}, \mathrm{CDCl}_{3}\right) \delta$ 148.93, $148.88,140.74,132.37,132.18,129.69,127.82,113.44,111.92,61.92,61.88,21.55,16.56$, 16.51. To the purified intermediate $(3.74 \mathrm{~g}, 14.7 \mathrm{mmol}), \mathrm{N}$-bromosuccinimide $(2.61 \mathrm{~g}, 14.7$ mmol) and 2,2'-azobis(2-methylpropionitrile) $(241 \mathrm{mg}, 1.47 \mathrm{mmol})$ was added to $60 \mathrm{ml}$ of carbon tetrachloride and the mixture was refluxed at $90{ }^{\circ} \mathrm{C}$ overnight. The reaction mixture was cooled by an ice-water bath and filtered to remove the precipitate. The filtrate was washed with $50 \mathrm{~mL}$ of water and $50 \mathrm{ml}$ of brine. The $\mathrm{CCl}_{4}$ layer was dried with anhydrous $\mathrm{MgSO}_{4}$ and filtered. The solvent was removed using rotary evaporator and the flash chromatography was used to purify using $75 \%$ ethyl acetate with $25 \%$ hexane. The isolated product 6.37 ( $2.3 \mathrm{~g}, 47 \%)$ was mixed with a small amount $(<5 \%)$ of starting material. The mixture was used for the alkylation described above for 1e without further purification. ${ }^{1} \mathrm{H}$ NMR $(500 \mathrm{MHz}, \mathrm{CDCl} 3) \delta$ 7.69-7.29 (m, 6H), $6.26(\mathrm{t}, J=17.4 \mathrm{~Hz}, 1 \mathrm{H}), 4.48(\mathrm{~s}, 2 \mathrm{H}), 4.21-4.09(\mathrm{~m}, 4 \mathrm{H}), 1.35(\mathrm{t}, J=6.9 \mathrm{~Hz}$, $6 \mathrm{H}) .{ }^{13} \mathrm{C}$ NMR $(126 \mathrm{MHz}, \mathrm{CDCL} 3) \delta 147.94,147.88,139.96,135.16,134.97,129.68,128.23$, $115.70,114.18,62.06,62.01,32.80,16.56,16.51$. 


\section{References:}

1. Ha, Y.; Facchetti, A.; Marks, T. J. Chem. Mater. 2009, 21, 1173-1175.

2. 1. Cristau, H.; Pirat, J.; Drag, M.; Tetrahedron Lett. 2000, 41, 9781-9785. 


\section{NMR Spectra for 1a-e}
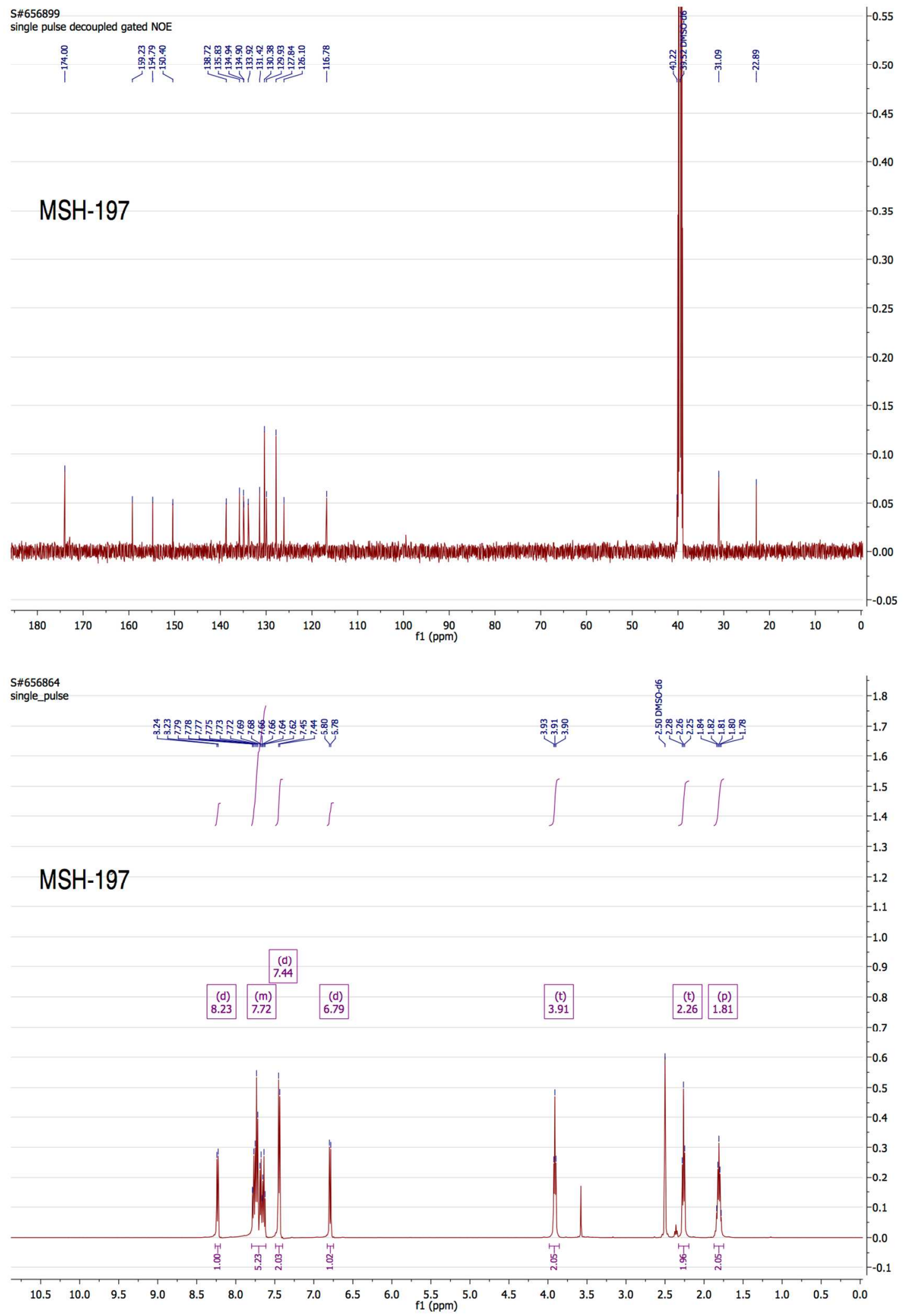


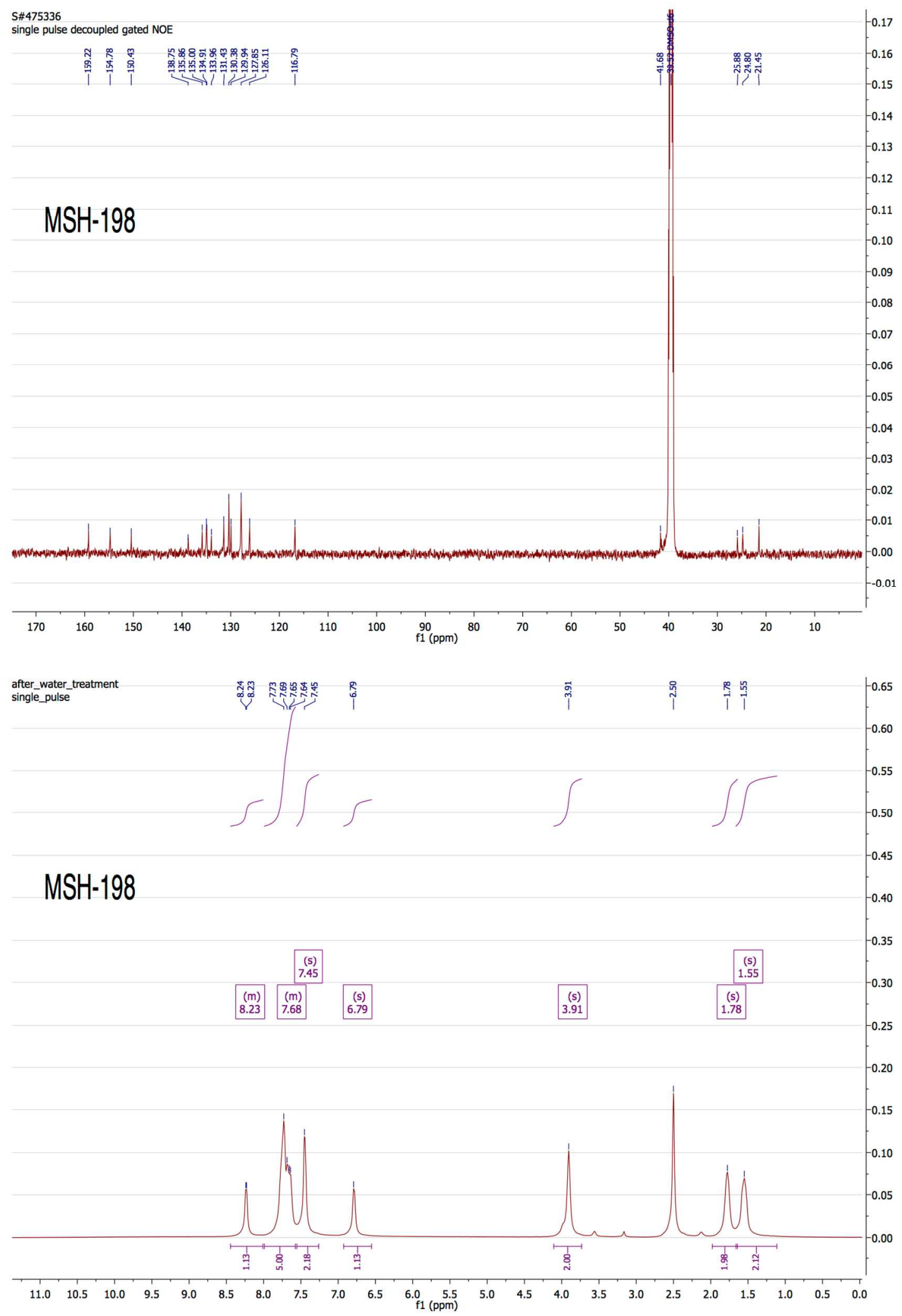




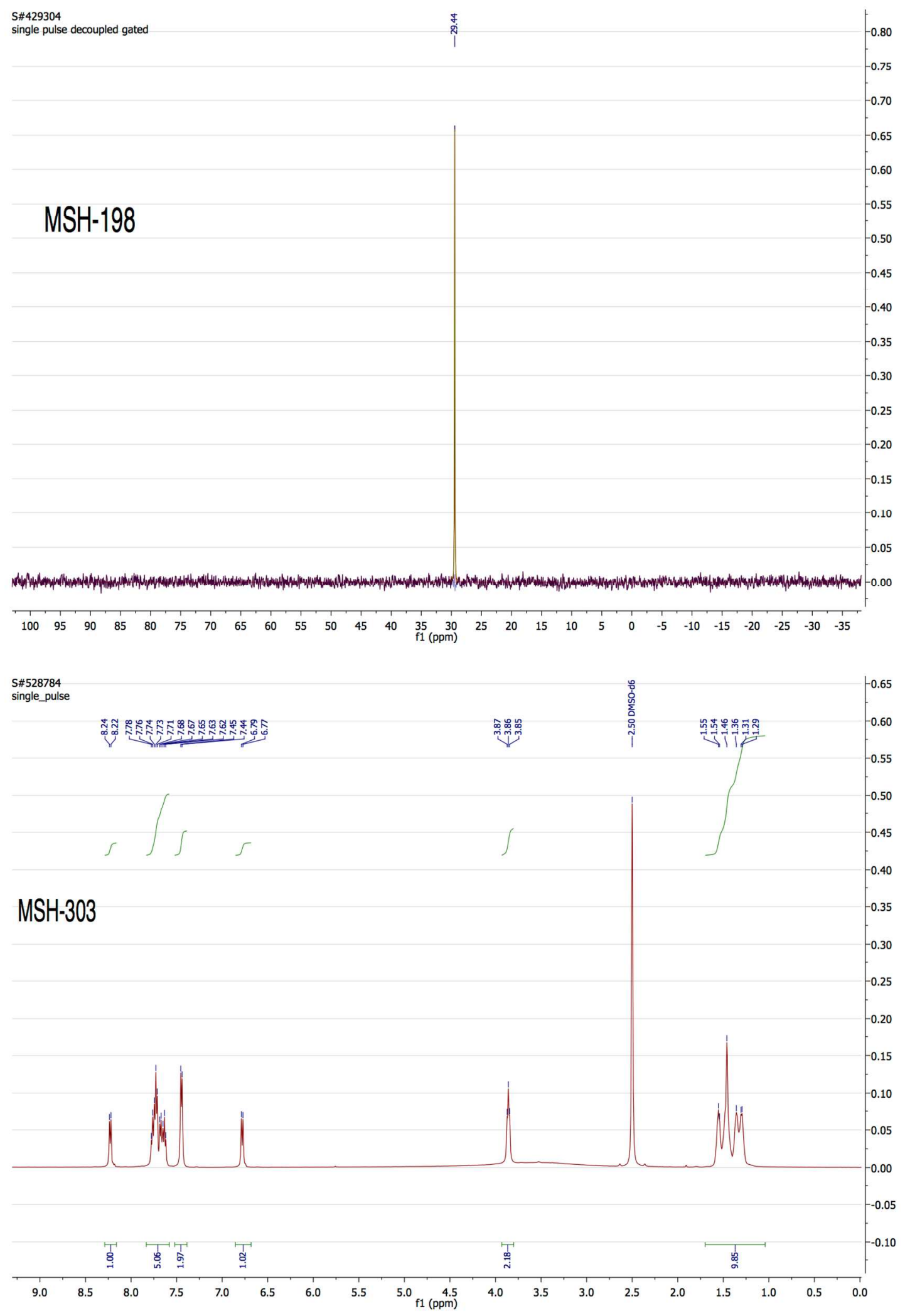




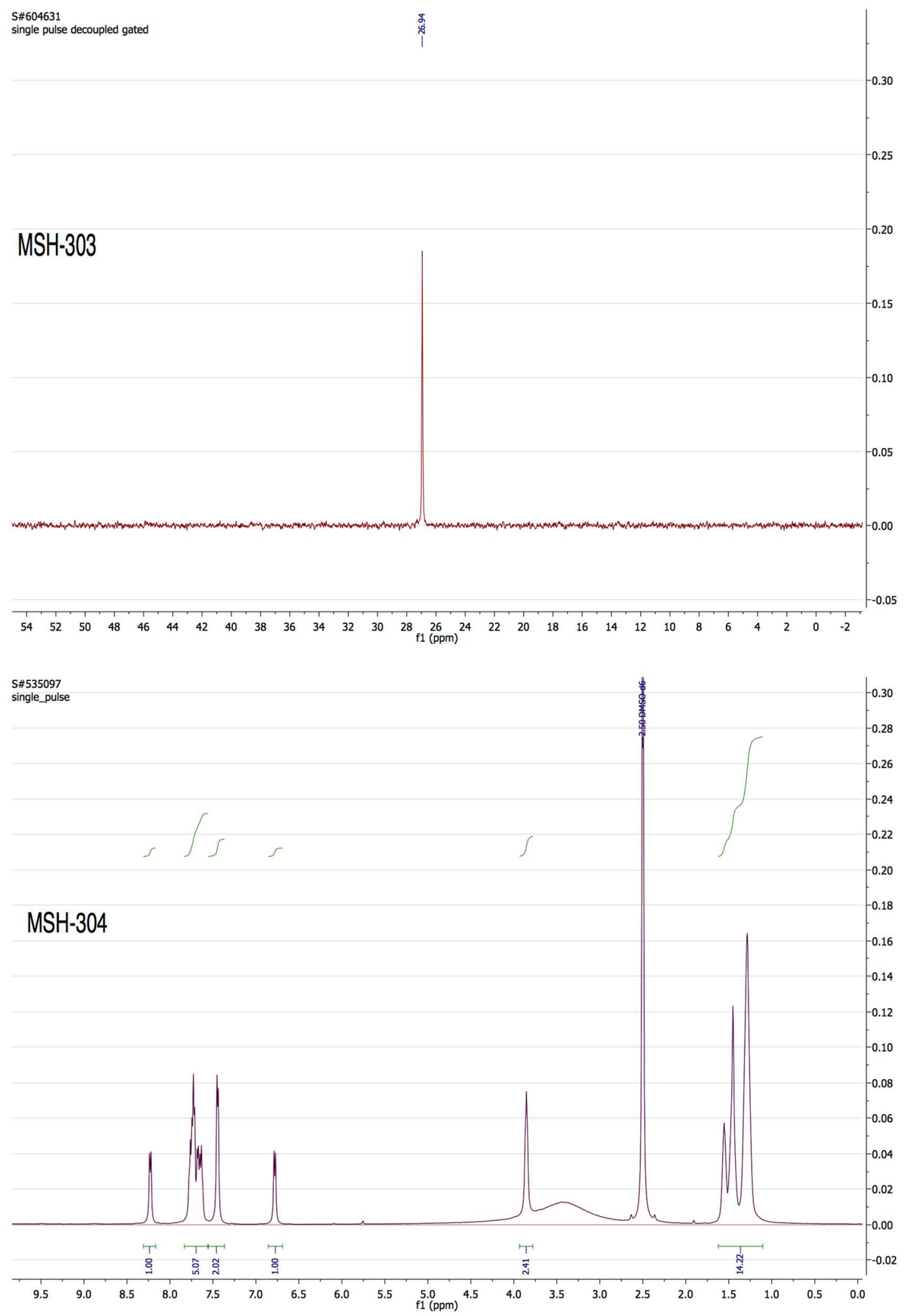




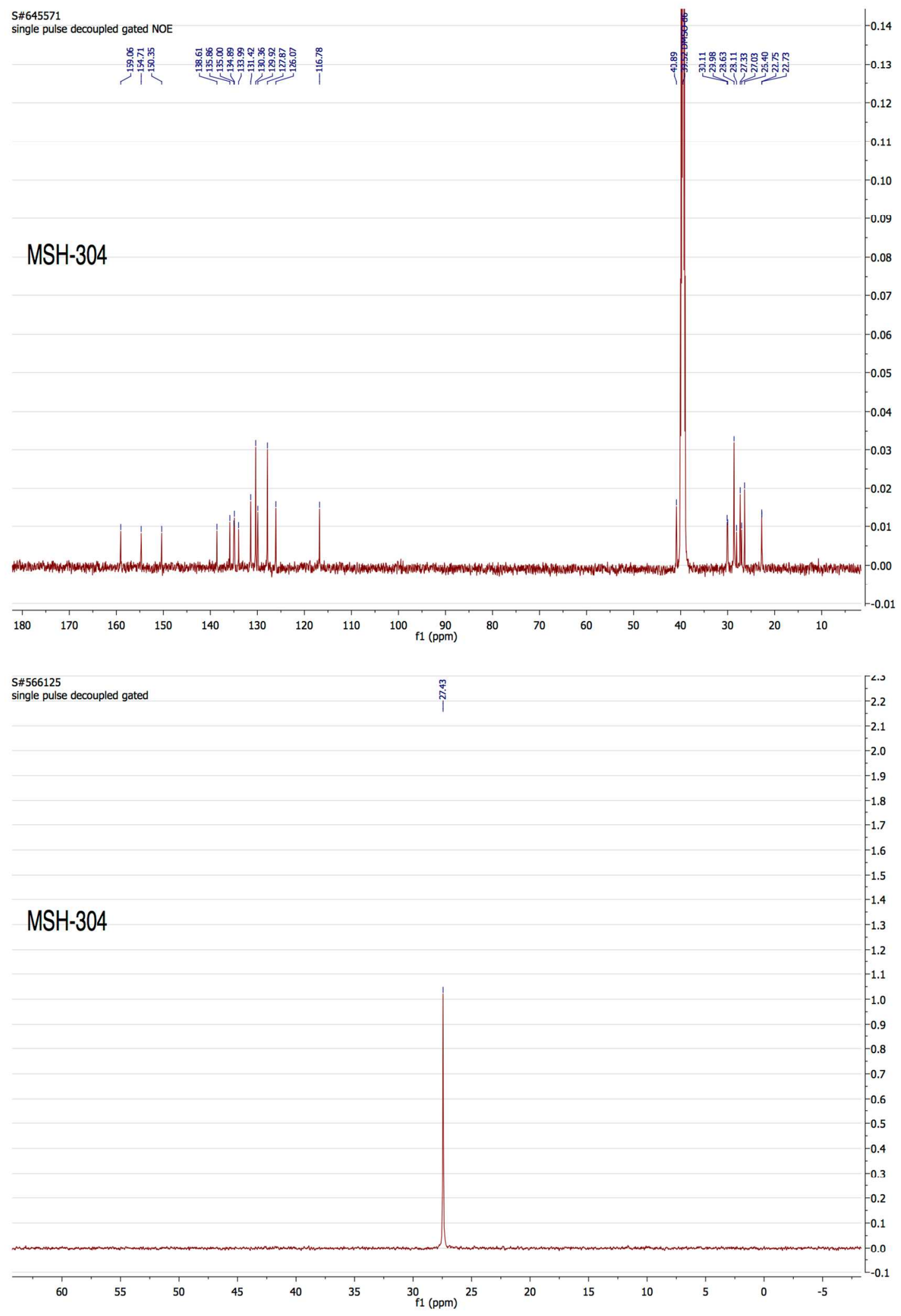

S-16 


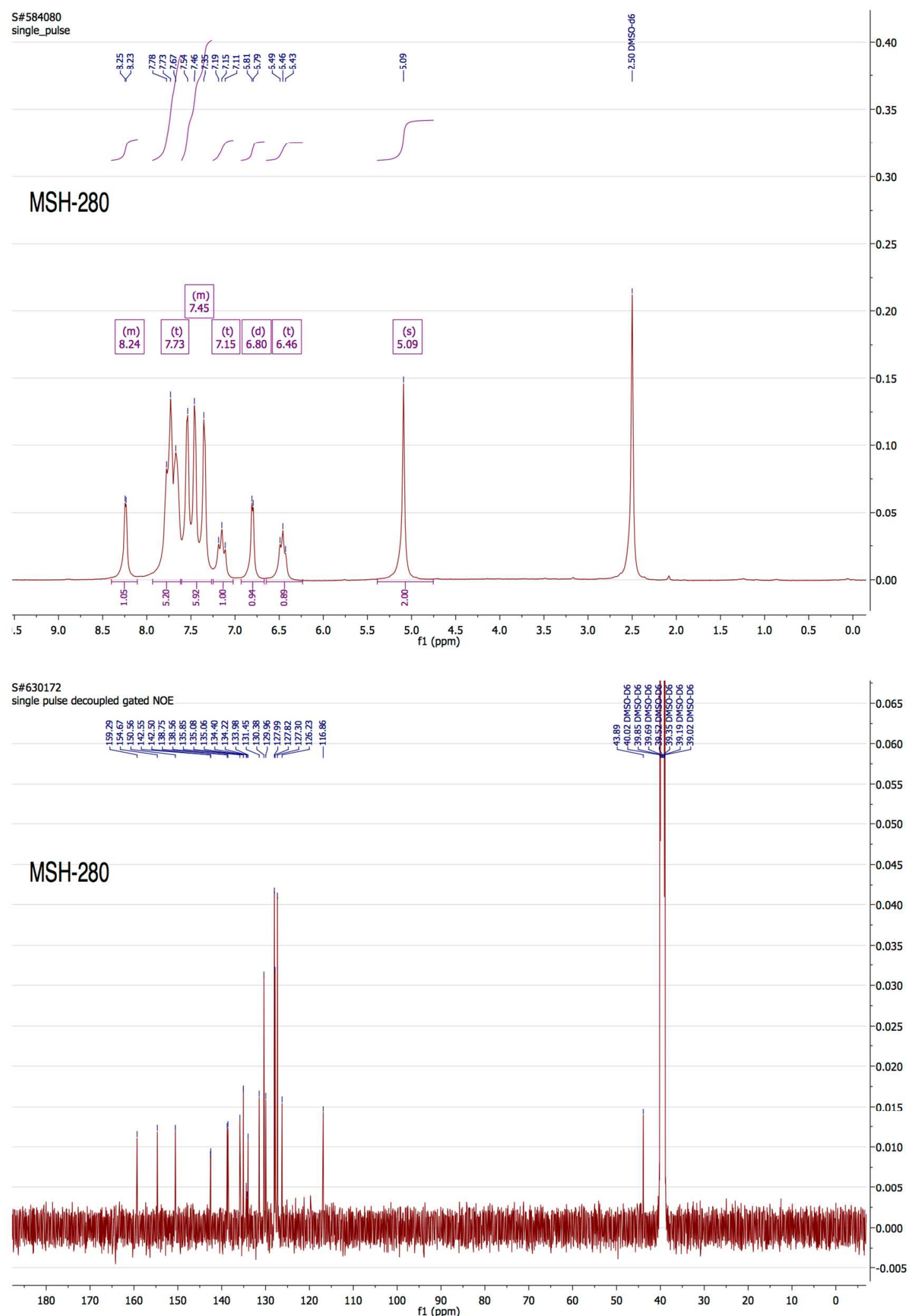




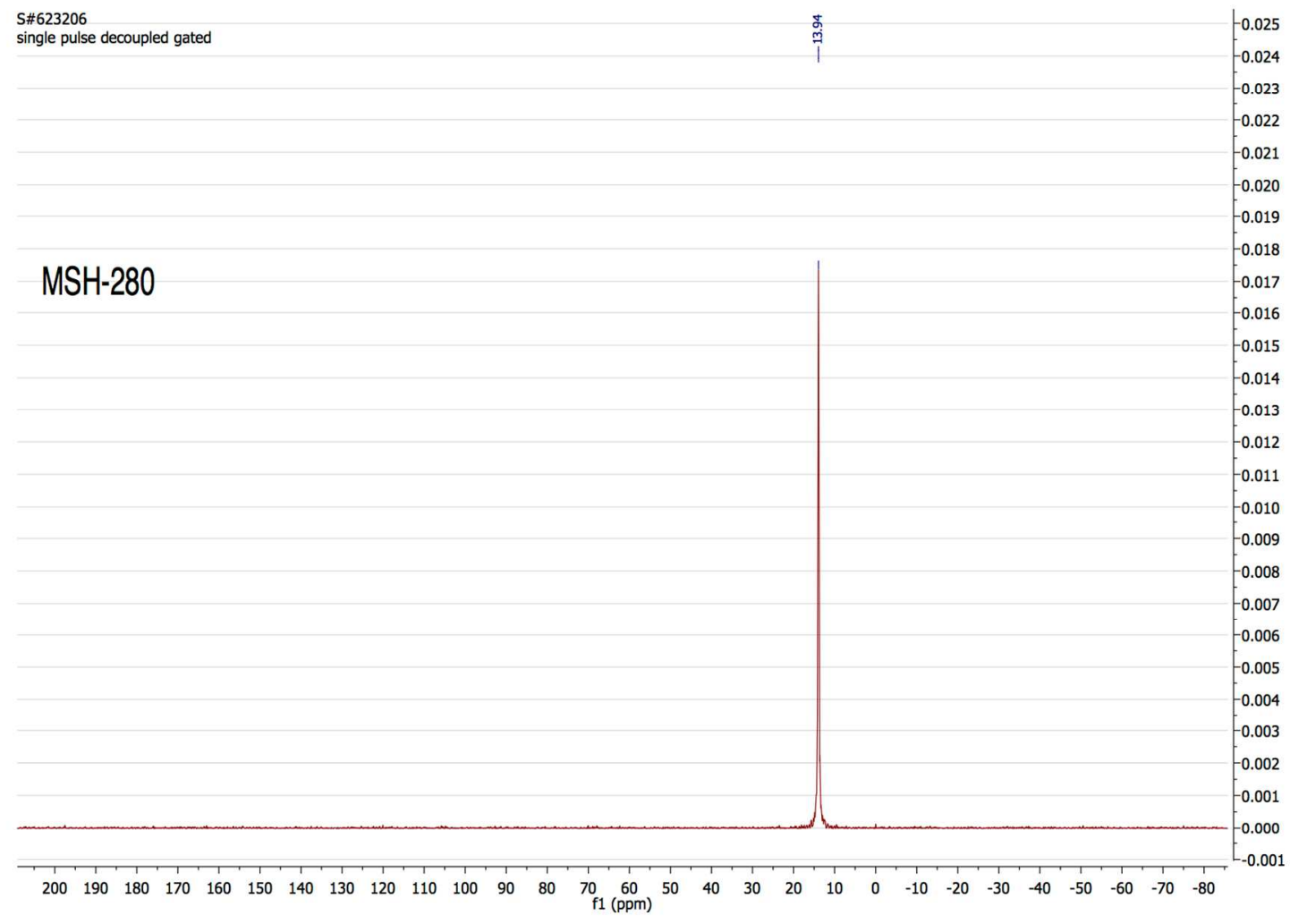

S-18 


\section{XRD and SEM Data on BiOCI Particles}

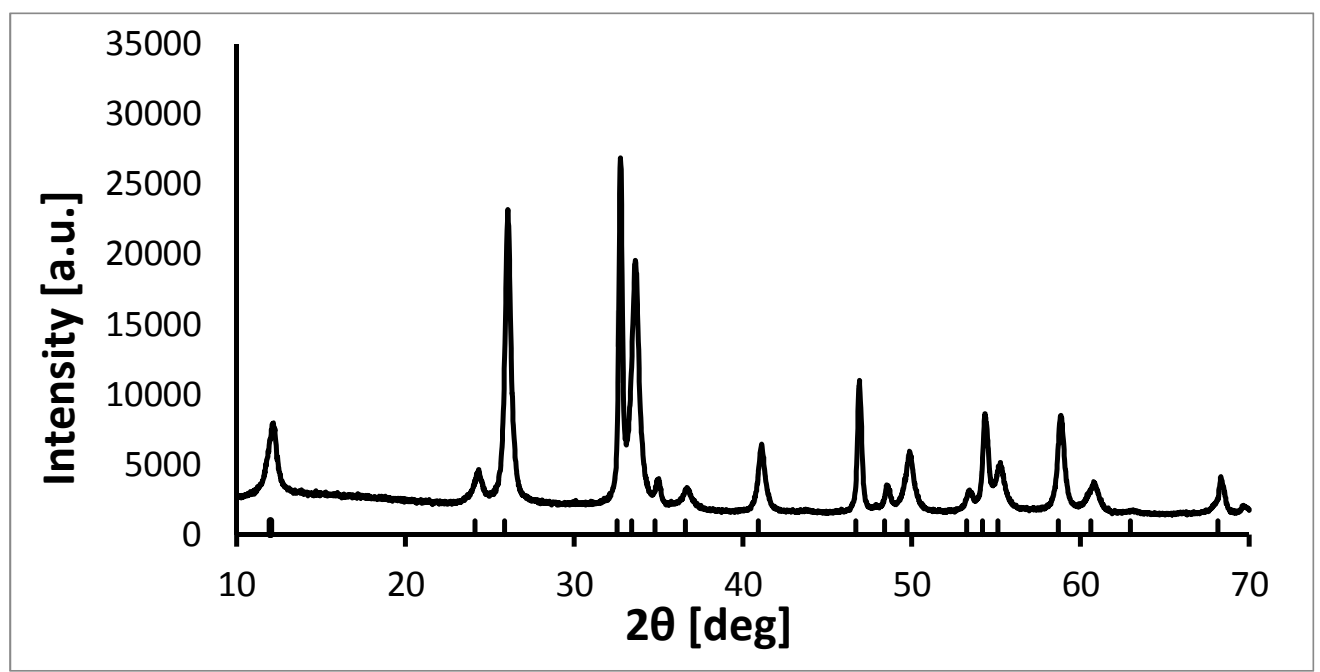

Figure S1. XRD pattern of BiOCl particles synthesized for this study.

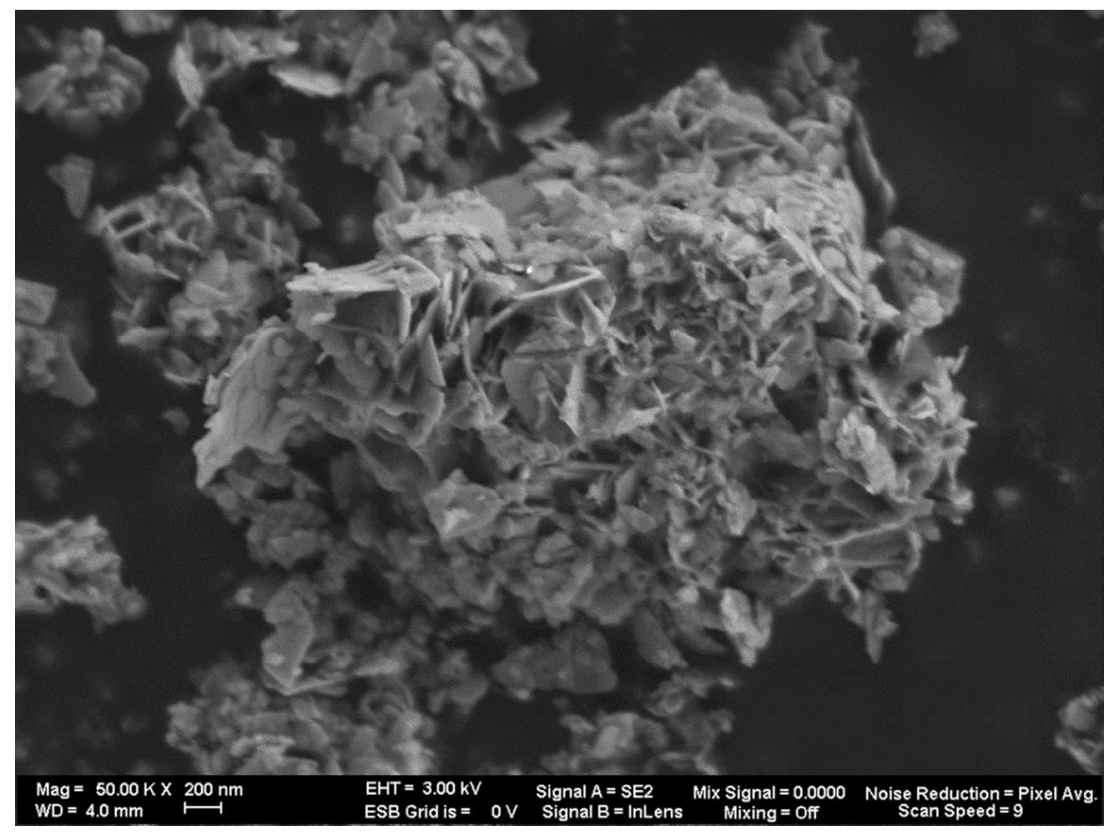

Figure S2. SEM image of BiOCl particles synthesized for this study; note the agglomerated particles comprised of nanoplatelets (refer to main text.). 


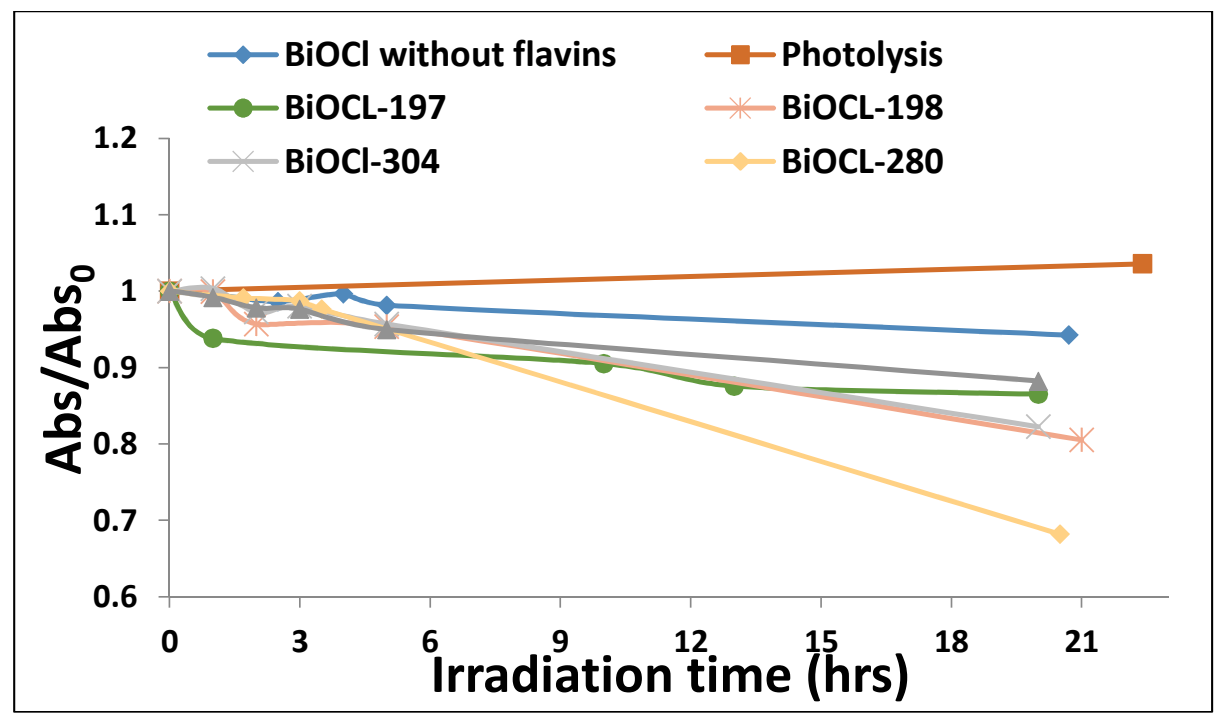

Figure S3. Photocatalytic (PC) degradation kinetics data on salicyclic acid and flavinated BiOCl particles, used for extracting the information contained in Table 1 in the main paper. Two controls are also included for comparison.

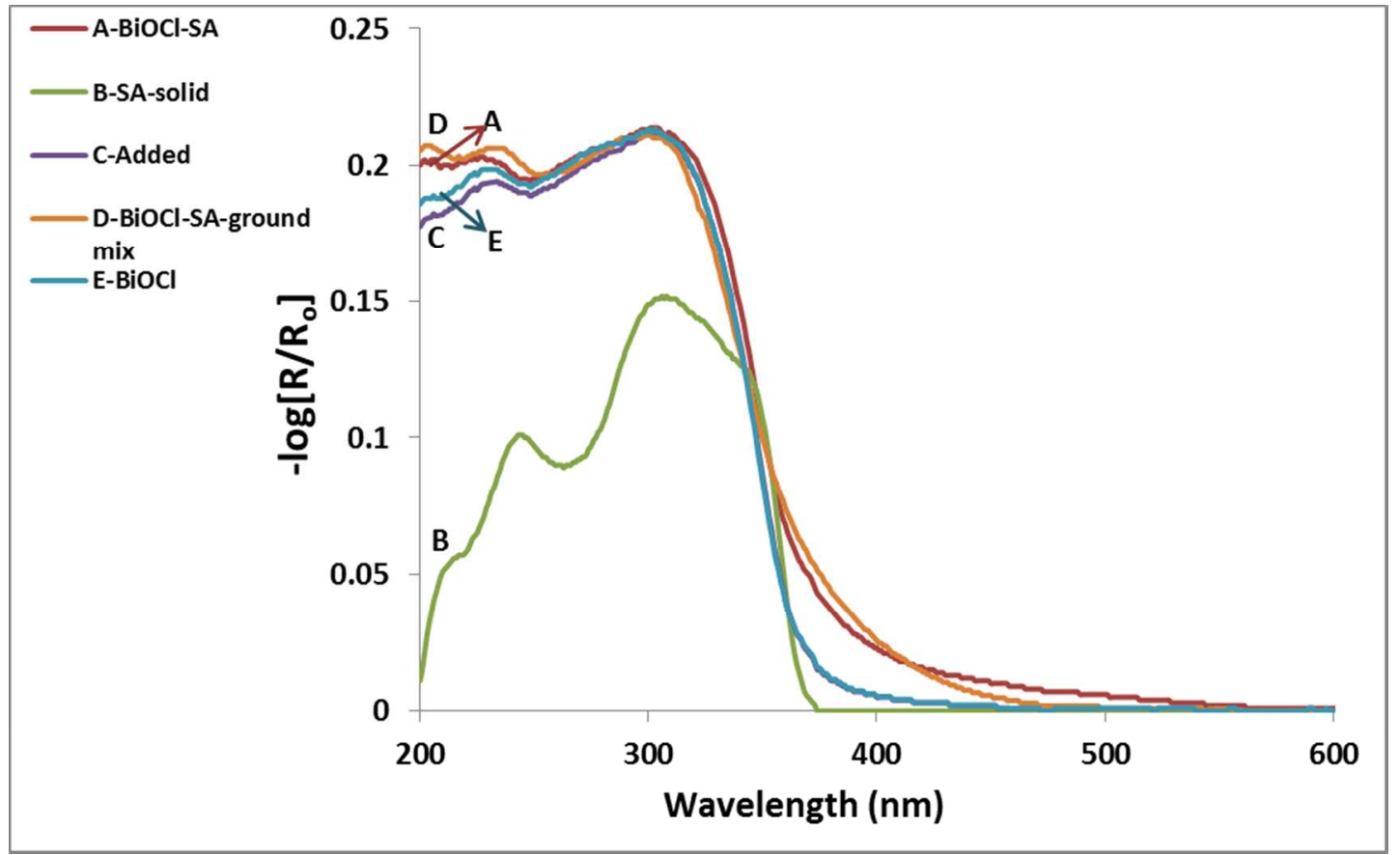

Figure S4. Diffuse reflectance UV-Vis data examining the possibility of charge transfer (CT) complex formation between the $\mathrm{BiOCl}$ particles and $\mathrm{SA}$ (refer to discussion in the main paper).) 